\title{
REVIEW
}

\section{Hormonal regulation of apolipoprotein AI}

\section{G M Hargrove, A Junco and N C W Wong}

Departments of Medicine and Biochemistry \& Molecular Biology, the Faculty of Medicine, University of Calgary, Calgary, Alberta, Canada, T2N 4N1.

(Requests for offprints should be addressed to N C W Wong, Departments of Medicine and Biochemistry and Molecular Biology, Faculty of Medicine, University of Calgary, Health Sciences Center, 3330 Hospital Drive NW, Calgary, Alberta, Canada T2N 4N1)

\begin{abstract}
Apolipoprotein AI (apo AI) is the major protein component of the serum high-density lipoprotein (HDL) particles. The antiatherogenic properties of apo AI alone or as part of HDL and their inverse correlation with the incidence of coronary heart disease underlie the clinical importance of the protein. A detailed understanding of the mechanisms by which apo AI is regulated will help us develop new and better ways to manipulate expression of the protein. Although there are many factors that influence apo AI expression, endogenous hormones are attractive because simple changes in abundance of these compounds will alter gene activity. Hormones belonging to the thyroid/steroid family that influence activity of the gene include
\end{abstract}

thyroid hormone, glucocorticoids, gender-specific steroids and retinoic acid. Whereas thyroid, glucocorticoid and estradiol enhance activity of the gene, retinoic acid and androgens decrease it. The mechanisms that mediate the effects of the hormones include direct effects of the ligand and nuclear receptor complex on gene activity. However, indirect means involving the participation of transcription factors other than the hormone receptors are also possible. In summary, members of the same hormone family may have different mechanisms that mediate their activities on apo AI gene activity.

Fournal of Molecular Endocrinology (1999) 22, 103-111

\section{INTRODUCTION}

Apolipoprotein AI (apo AI) is the major protein component of high-density lipoprotein (HDL) particles in serum. These particles have an important role in the protection against arteriosclerotic vascular disease, because they provide a shuttle mechanism that transports cholesterol from extrahepatic tissues to the liver for processing to bile salts (Miller et al. 1985, Franceschini et al. 1991). This pathway is a normal physiologic process called reverse cholesterol transport ( $\mathrm{RCT})$, and the end result of this process leads to lower concentrations of total cholesterol (Kashyap 1989). As hypercholesterolemia is one of the modifiable risk factors underlying ischemic heart disease, currently the most important cause of premature death in the world (Murray \& Lopez 1997), new ways to lower cholesterol are of interest to both the medical community and the general population.

The knowledge that apo AI alone or as part of HDL has antiatherogenic properties (Miller 1987, Barter \& Rye 1996, Luoma 1997) provides the rationale for many investigators to examine the specific factors that regulate expression of the gene. A better understanding of how the gene is regulated will help us design new therapies to manipulate expression of the protein and thus augment RCT. The ability to control RCT is expected to benefit members of the population who suffer from arteriosclerotic vascular disease.

Well known factors that have a beneficial effect on the abundance of apo AI protein include: physical excercise (Huttunen et al. 1979, Ballantyne et al. 1982, Danner et al. 1984), alcohol consumption (McConnell et al. 1997, Manttari et al. 1997) and 


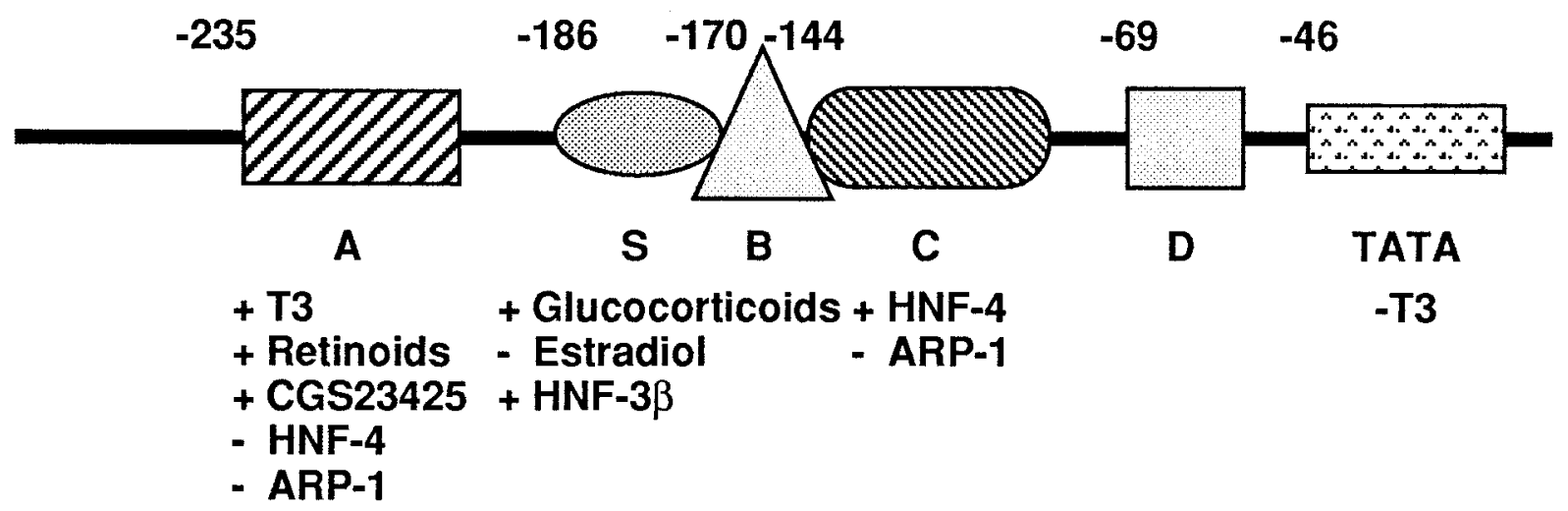

FIGURE 1. Schematic representation of the apolipoprotein AI promoter. The cis-acting elements are shown by both geometric shapes and the most $5^{\prime}$ nucleotide for each site. Listed below each of the sites, A, S, B, C, D and TATA, are the hormones or compounds and transcription factors that act at these sites. The $+/-$ signs indicate whether the hormones, compounds or transcription factors have a positive or negative effect on the site.

being female (Heiss et al. 1980). These factors increase concentrations of apo AI protein. Recent studies show that pharmacologic agents such as fibrates, phenytoin and phenobarbital also modulate the concentrations of this protein (Nikkila et al. 1978, Kaste et al. 1983, Muuronen et al. 1985, Reddy 1985). In addition to the preceding pharmacologic agents, a host of natural hormones also influence apo AI protein concentrations. A better understanding of the mechanisms by which hormones regulate apo AI concentrations is particularly attractive, because this knowledge offers potentially useful information to help us manipulate apo AI expression by adjusting concentrations of the specific hormone or using analogs of the parent hormone. The list of hormones known to enhance or suppress apo AI protein include thyroid hormones (Apostolopoulos et al. 1987, Strobl et al. 1990), glucocorticoids (Elshourbagy et al. 1985, Ettinger et al. 1987), sex steroids (Kalin \& Zumoff 1990) and retinoic acids (Zech et al. 1983). Most of these hormones exert effects at the gene level; a schematic diagram of the apo AI promoter and the respective cis-acting elements that mediate the effects of these hormones is presented below (Fig. 1). This review summarizes the knowledge of the mechanisms by which these compounds influence apo AI expression. The information provides a framework for the development of new directions in this field of research.

\section{Thyroid hormones}

The hormones synthesized by the follicular cells of the thyroid gland were amongst the first observed to affect cholesterol metabolism. Hypercholestero- lemia was a useful marker for the diagnosis of hypothyroidism in patients before the general availability of rapid measurements of thyroid function. This abnormality was described in studies of hypothyroid patients conducted more than 60 years ago (Mason et al. 1930). Since then, numerous investigators have attempted to elicit the mechanisms responsible for the changes in lipid metabolism underlying hypercholesterolemia. Both the thyroid hormones, L-thyroxine $\left(\mathrm{T}_{4}\right)$ and L-triiodothyronine $\left(\mathrm{T}_{3}\right)$, are believed to have a variety of effects on the concentration of cholesterol. For example, in the presence of thyroid hormones, hepatic synthesis of cholesterol is actually enhanced (O'Hara et al. 1966), adding to the concentration of total cholesterol, but these hormones also increase the fractional clearance rates of very-low-density lipoprotein and low-density lipoprotein (LDL) particles (Rossner \& Rosenqvist 1974, Abrams et al. 1981), in addition to the hepatic excretion of cholesterol (Miettinen 1968). The net effect of the opposing actions of the hormones in the liver gives rise to greater concentrations of cholesterol in hypothyroid individuals compared with those with euthyroid or hyperthyroid levels of the hormones.

Pertinent to this review are the effects of thyroid hormone on HDL concentrations and how these changes contribute to total cholesterol. In patients with hyperthyroidism, the concentrations of HDL cholesterol are generally lower (Scottolini et al. 1980, Valdemarsson 1983) than those in patients with hypothyroidism (Feely et al. 1980, Scottolini et al. 1980). However, other studies show decreased concentrations of HDL cholesterol in patients with hypothyroidism (Abrams \& Grundy 1981). In addition, the different classes of HDL particles 
appear to be affected differently by thyroid hormone (Aviram et al. 1982, Kris-Etherton et al. 1982). This lack of a uniform effect is mirrored in the studies of hypothyroid patients treated with thyroid hormone leading to variable outcomes (Wahlqrist et al. 1977, Ballantyne et al. 1979, Brun et al. 1980, Engelken \& Eaton 1980, Malkonen \& Manninen 1981, Aviram et al. 1982, Raziel et al. 1982). Part of this lack of uniformity may arise from the fact that HDL particles are synthesized by two tissues in the body - liver and small intestine (Smith et al. 1978).

A better understanding of the actions of thyroid hormones on apo AI expression comes from animal studies and cell culture models. In vivo studies in rodents show that thyroid hormone increases the concentrations of apo AI protein and the corresponding mRNA (Romney et al. 1992, Mooradian et al. 1996). There is debate whether changes in transcription of the gene match the observed increase in the protein and mRNA after exposure to thyroid hormone (Vandenbrouck et al. 1995). Given this controversy, subsequent studies have used cell culture models to examine the effects of the hormones on transcription of the apo AI gene, using transient transfection experiments. The extension of promoter studies to cell culture models is based on the examination of motifs within the apo AI promoter that resemble $\mathrm{T}_{3}$-response elements (TRE) (Taylor et al. 1996b). A motif that resembles a positive TRE is located between -208 and -193 in the rat apo AI promoter, and corresponds to a similar sequence in the human gene between -214 and -192 (Rottman et al. 1991). This site matches the typical consensus TRE, except that the 6-bp repeats are separated by $2 \mathrm{bp}$, rather than $4 \mathrm{bp}$, of non-specific nucleotide sequence. When this site is intact, the response of the promoter is induced by $\mathrm{T}_{3}$ and this positive effect requires the presence of the $\mathrm{T}_{3}$-receptor (TR) (Romney et al. 1992, Taylor et al. 1996b). Furthermore, when this $\mathrm{T}_{3}$-response element, TRE, was fused to the SV40 viral promoter, $\mathrm{T}_{3}$ and its receptor caused a fourfold induction in the activity of the chimeric construct (Romney et al. 1992). Additional proof that the element from apo AI DNA was indeed a TRE comes from studies showing that TR binds to this sequence in the form of either a homodimer or a heterodimer, comprised of TR and retinoic acid receptor- $\alpha$ (RXR $\alpha)$ (Taylor et al. 1996b). The dominant actions of thyroid hormone on the apo AI promoter are mediated by the TRs, TR $\alpha$ and TR $\beta$. These proteins belong to a superfamily of ligand receptors that also function as nuclear transcription factors (Beato et al. 1995, Laudet 1997). This superfamily of receptors includes those that bind to the thyroid and steroid hormones. The actions of these receptors are regulated by the binding and dissociation of specific hormones. In addition to TR, the apo AI-positive TRE may also bind two orphan members of the receptor superfamily: ARP-1 (Ladias \& Karathanasis 1991) and HNF-4 (Sladek et al. 1991). The interaction of the various members of the receptor superfamily binding to the positive TRE contributes to the regulation of apo AI gene activity (Fuernkranz et al. 1994, Ginsburg et al. 1995, Murao et al. 1997).

The positive TRE is not the only $\mathrm{T}_{3}$-responsive motif within the apo AI promoter that mediates the effect of thyroid hormone. Upon removal of the positive TRE, $T_{3}$ had a suppressive effect on the deletional construct and this observation led to the identification of a negative TRE fused to the $3^{\prime}$ end of the TATA-element in the apo AI promoter (Taylor et al. 1996b). This negative TRE also binds to TR. A comparison of the nucleotide sequence of the negative and positive TRE shows that, whereas the positive TRE is comprised of two 6-bp repeats (Naar et al. 1991, Umesono et al. 1991), the negative element also had the same 6-bp motif, but only a single copy (Carr \& Wong 1994, Carr et al. 1992, Taylor et al. 1996b). Thus it is not surprising to find the binding of TR dimer to the positive TRE and a monomer to the negative TRE (Taylor et al. 1996b). The results from these studies show the dual effects of thyroid hormone on apo AI gene activity. This information has already proven useful in the research and development of thyromimetics that may eventually prove to be useful in regulating levels of apo AI expression (Taylor et al. 1997).

\section{Glucocorticoids}

The clue that glucocorticoids affect the expression of apo AI comes from clinical observations showing that serum concentrations of both apo AI protein and HDL are increased in patients with endogenous or exogenous glucocorticoid excess (Ettinger et al. 1987). This finding of a stimulatory action of glucocorticoids in humans has been extended to animals, and these models are useful for examining the mechanisms that underlie the actions of glucocorticoids. For example, rats given oral doses of the synthetic glucocorticoid, dexamethasone, on four consecutive days exhibited a twofold increase in hepatic apo AI mRNA (Elshourbagy et al. 1985). Similarly, rats injected with the steroid had threeto fourfold greater concentrations of apo AI in the serum and this was matched by a corresponding four- to sixfold induction of the mRNA in liver (Taylor et al. 1996a). Other investigators treated male rats with hydrocortisone for 20 days and found that the concentration of plasma apo AI increased to 
$150 \%$ of that in controls, and this finding was accompanied by a twofold increase in levels of the mRNA (Staels et al. 1991). In support of the data from animal models, the glucocorticoids also increase apo AI mRNA and augment synthesis of the protein in hepatoma cell lines (Masumoto et al. 1988, Varma et al. 1992). These observations clearly show that glucocorticoids increase apo AI gene expression in both in vitro and in vivo models.

Although one of the mechanisms by which glucocorticoids exert their effect involves their binding to a nuclear receptor, the resulting complex controlling gene activity, the effect of the steroid on apo AI expression is mediated by a different pathway. Recent results of experiments in our laboratory indicate that the stimulatory effects of glucocorticoids do not appear to require the binding of the glucocorticoid receptor, GR, to apo AI DNA (Taylor et al. 1996a). Glucocorticoids definitely have a transcriptional effect, as demonstrated by 'run-on' studies in hepatic nuclei of rats injected with dexamethasone. These showed that transcription of the apo AI gene was two- to threefold greater in treated animals compared with controls. Additional supportive evidence that glucocorticoids have a transcriptional effect on apo AI comes from transient transfection studies in $\mathrm{HuH} 7$ cells, a fetal hepatoma cell line known to contain the GR (Nakabayashi et al. 1989). Consistent with this finding, the introduction of chloramphenicol acetyl transferase (CAT)-reporter constructs containing the apo AI promoter in the presence of dexamethasone stimulated CAT-activity $3 \cdot 1$-fold. Furthermore, the internal deletion of site $B(-170$ to 145$)$ from the promoter completely abolished the stimulatory effects of glucocorticoids (Taylor et al. 1996a). The B-motif is comprised of two nonanucleotide repeats in a head-to-tail orientation separated by four base pairs (Chan et al. 1993, Harnish et al. 1994). Both of these repeats appear to be critical for the response of the motif to glucocorticoids, because disruption of either 9-bp repeat inhibited the activity of the entire motif. Next, results of electrophoretic mobility shift studies showed that the GR does not bind to site B. However, dexamethasone clearly induced site B binding activities, but these activities were not attributed to the GR. Nonetheless, the receptor has an important role in the light of recent results showing that the GR antagonist, RU486, added to rat hepatoma cells (McARH8994 cells) completely blocks the increase in apo AI mRNA that follows treatment with dexamethasone (Saladin et al. 1996). In addition, the presence of the receptor alone is not sufficient, as treatment of COS-1 cells, which lack endogenous GR, with dexamethasone did not increase apo AI promoter activity in the presence of transfected GR, suggesting that the receptor acts via an indirect mechanism. Such a mechanism could involve GR activation of a factor that, in turn, binds to site B. Previous data showing that the induction of rat apo AI mRNA by dexamethasone is blocked by cycloheximide, a compound that inhibits protein synthesis, provide additional support for an indirect effect of glucocorticoids (Wong \& Oppenheimer 1986). The conclusion based on these observations is that glucocorticoid-stimulated expression of apo AI is mediated by an indirect mechanism, perhaps through enhancement of the actions of transcription factor(s) that in turn activate the promoter.

Site B appears to be the mediator of glucocorticoid activity, and recent studies have shown that it has the potential to bind dimers of the transcription factor, hepatic nuclear factor-3 (HNF-3). In fact, previous studies (Harnish et al. 1994, 1996) have demonstrated that HNF-3 $\beta$ binds to the B-motif in human apo AI DNA and increases transcription of the gene. As glucocorticoid induces site $\mathrm{B}$ binding activities (Taylor et al. 1996a), and HNF-3 $\beta$ is one of the transcription factors that binds to this site in the human apo AI promoter, then the stimulatory effect of glucocorticoids on expression of the gene may act via increased abundance or activity of $\mathrm{HNF}-3 \beta$.

Although the preceding summary focuses on the transcriptional effects of the steroid, posttranscriptional effects of glucocorticoid on apo AI gene expression are also possible. If transcription and translation alone are responsible for the steroid-induced increases in apo AI and these sequential processes have reached equilibrium, then the fold induction attributed to each process should be equal. However, apo AI transcription was increased two- to threefold, mRNA levels five- to sixfold and secreted protein three- to fourfold, which raises the possibility that glucocorticoids may have additional post-transcriptional effects that are yet to be elucidated.

\section{Gender-specific steroid hormones}

The risk of ischemic heart disease is approximately twofold greater in men than in women (Kalin \& Zumoff 1990). In part, this differential in the risk of acquiring the disease is attributed to the actions of the sex steroids (Kalin \& Zumoff 1990) on serum lipoprotein concentrations (Godsland et al. 1987). Estrogens increase the concentrations of apo AI protein in females; in contrast, testosterone decreases abundance of HDL in both sexes (Godsland et al. 1987, Sacks et al. 1995) and thus gives rise to a more atherogenic profile. Although the clinical observations 
are straightforward, the mechanisms by which the sex steroids influence the plasma concentrations of apo AI are far from being simple.

The complex nature of estrogen effects arises from the involvement of the hormone in multiple steps of lipoprotein metabolism. For example, clinical studies show that estrogen replacement therapy in post-menopausal women increases apo AI concentrations by suppressing the activity of hepatic triglyceride lipase (HTGL) (Hazzard et al. 1984, Applebaum-Bowden et al. 1989, Colvin et al. 1991, Quintao et al. 1991). In addition, other clinical studies showed that the hormone also increases synthesis of the lipoprotein (Schaefer et al. 1983, Sacks et al. 1995). Unlike clinical studies, with their restrictions, animals models make it possible to examine specific steps in apo AI gene expression that are influenced by the hormone. Thus, in support of the stimulatory effects of estrogen on apo AI expression, rodents treated with pharmacologic doses of estrogen were found to have greater concentrations of apo AI mRNA and gene transcription. Although these actions should give rise to higher levels of apo AI protein, the hormone also had post-transcriptional effects that decreased the abundance of the protein (Seishima et al. 1991, Tang et al. 1991, Srivastava et al. 1993). For example, pharmacologic doses of estrogens enhance LDL receptor (LDLR) activity, thereby decreasing apo AI (Windler et al. 1980, Srivastava et al. 1993, Croston et al. 1997). Thus it is evident that estrogens regulate many aspects of apo AI gene expression.

Given the possibility that estrogens affect several steps of apo AI expression, investigators have turned to the use of cell lines to address specific questions. Consistent with the observations in vivo, the exposure of Hep G2 cells to estrogen increases the concentrations of apo AI protein, and this effect is dependent on the amount of hormone (Archer et al. 1986, Tam et al. 1985). In addition, increases in apo AI mRNA correlate well with the increase in the concentrations of the protein (Archer et al. 1986). Further studies in Hep G2 cells showed that this cell line contained two estrogen-binding activities in the nucleus, with different affinities for the hormone. Estrogen induction of apo AI protein and mRNA correlated with the higher-affinity site. The addition of estrogen concentrations beyond those required to saturate the nuclear binding activity had minimal effects on induction of apo AI (Archer et al. 1986, Tam et al. 1986). These results show that estrogen affects apo AI expression via the estrogen receptor by regulating either gene transcription or mRNA stability. Results of recent studies suggest that the steroid influences transcrip- tion of the gene (Jin et al. 1998). However, the apo AI promoter does not contain a binding motif for the nuclear estrogen receptor.

The preceding reports suggest that the actions of the hormone on apo AI involve a receptor for estrogen; however, the lack of a recognizable estrogen receptor binding site in apo AI promoter points to an indirect effect of the hormone. In support of the latter idea, recent studies have examined the cis-acting sites and the respective nuclear factors that participate in the actions of the hormone. Results showed that estradiol potentiated the synergistic interactions between two transcription factors, HNF-4 and HNF-3 $\beta$ (Harnish et al. 1996), that bind to tandem cis-acting elements, sites A (Malik \& Karathanasis 1996, Murao et al. 1997) and B (Harnish et al. 1994) respectively. The synergism between HNF-4 and HNF-3 $\beta$ is believed to be mediated by factor(s) that influence proteinprotein interactions between the two proteins. Recent studies show that the co-repressor, RIP140, could fulfil such a role, and the activity of this factor is modulated by estradiol (Harnish et al. 1998). The current belief is that estradiol-activated endoplasmic reticulum somehow sequesters RIP140 protein, leading to the relief of repression and thus greater levels of apo AI gene transcription.

This section can deal only briefly with the effects of androgens on apo AI expression, because there is less information on this topic compared with that of estrogens. In general, androgens act in a fashion opposite to that of estrogen. For example, androgens upregulate HTGL activity (Larosa 1995) and antagonize the estrogen induction of (low density lipoprotein receptor (LDLR) activity (Croston et al. 1997). Although experiments in animals show that testosterone influences apo AI gene activity (Tang et al. 1991), the results of cell culture studies suggest that the hormone acts by antagonizing the actions of estrogen, and that androgens have no direct effect on gene transcription (Tam et al. 1986).

In summary, the sex hormones influence both catabolic rates and hepatic synthesis of apo AI. The effects on hepatic synthesis are complex and involve the regulation of gene expression at several levels. Estrogen upregulates apo AI promoter activity by influencing the synergy between $\mathrm{HNF}-3 \beta$ and $\mathrm{HNF}-4$ at sites $\mathrm{B}$ and A respectively. Androgens are believed to block the actions of estrogens.

\section{Retinoic acids}

Retinoids are commonly used in the clinical setting to treat a wide range of dermatologic disorders, including nodulocystic acne, rosacea, severe psoriasis, disorders of keratinization, and the prevention 
of skin cancers. In humans, the synthetic retinoids, isotretinoin (13-cis retinoic acid) and etretinate (aromatic retinoid) induce significant increases in triglycerides, total and LDL cholesterol, but they have an opposite effect on HDL, leading to concentrations decreased by $10-24 \%$ (Zech et al. 1983, Melnik et al. 1987). These retinoid-induced alterations are felt to be detrimental because of a more atherogenic lipid profile that thus exposes the patients to the risk for developing premature cardiovascular disease. However, the changes associated with retinoids were ameliorated by administering fish oil that contained omega- 3 fatty acids in conjunction with retinoid therapy. In fact, the combined therapy led to an $11 \%$ increase in HDL concentrations (Ashley et al. 1988).

The mechanism by which retinoids regulate the apo AI component of HDL has been examined using both in vitro and in vivo model systems. When normal rats are treated with retinoic acid (RA), the effects on hepatic concentrations of apo AI mRNA are variable, with decreases ranging from 60 to $-70 \%$, but protein concentrations in the serum remain unchanged (Berthou et al. 1994). In contrast, other studies showed that RA increased concentrations of apo AI mRNA in small intestine, but there was no effect on abundance of hepatic mRNA (Nagasaki et al. 1994). However, vitamin A-deficient rats given excess RA had increased hepatic concentrations of apo AI mRNA (Nagasaki et al. 1994). Other investigators have assessed the actions of retinoids on the biosynthesis of apo AI in vitro using human intestinal and liver cancer cell lines, Caco-2 and HepG2 respectively. Exposure of Caco-2 cells to either all-trans or 9-cis RA increased both the abundance of apo AI mRNA and protein secretion by $40-80 \%$ above control. In Hep G2 cells or primary cultured hepatocytes, retinoids had a similar effect, leading to an induction of apo AI from $25 \%$ to $30 \%$ that matched secretion of the protein (Berthou et al. 1994, Kaptein et al. 1994, Giller et al. 1995). Furthermore, the stimulatory effect of RA on apo AI mRNA was completely blocked by actinomycin $\mathrm{D}$, thus pointing to an underlying transcriptional effect. These findings suggest that the actions of retinoids on synthesis of apo AI protein are opposite to those on the levels of HDL in serum, but that retinoids have a stimulatory or inhibitory effect on hepatic mRNA levels, depending on the model studied.

Evidence in support of the stimulatory effect of retinoids on apo AI gene expression comes from transient transfection studies of the promoter. Others (Rottman et al. 1991) showed that site A (bp -214 to -192 ) within the human apo AI promoter is a highly selective retinoic-acid-responsive element that responds preferentially to one member of the retinoic acid receptor family, RXR $\alpha$. Overexpression of RXR $\alpha$ exposed to $10^{-6}$ M RA activated a reporter construct containing four copies of site A to over 300 -fold above baseline. In addition, the authors showed that RXR $\alpha$ binds to radiolabeled site A. These findings appear to contradict the clinical data, in that effects of RA on apo AI transcription should, theoretically, increase the abundance of the protein and, hence, result in greater HDL concentrations. The explanation underlying the discordant effects of RA in clinical studies compared with those observed in animal and in vitro models is not clear. As retinoids are morphogens, the functions of which are most pronounced during development and cellular differentiation, it is conceivable that their stimulating effects on apo AI gene expression are restricted to the fetal or early neonatal period. This may explain why RA has a stimulatory effect in the fetal Hep G2 cells. Alternatively, the in vitro data may reflect accurately the apo AI gene activity at the cellular level in human/animal liver, but increased catabolism of the protein that surpasses the synthesis rate may result in a net reduction in serum apo AI protein and HDL levels. Regardless of the mechanism, it is clear that further studies are needed to test these hypotheses.

\section{ACKNOWLEDGEMENTS}

G M Hargrove is the recipient of a fellowship award from the Alberta Heritage Foundation for Medical Research (AHFMR). N C W Wong is the recipient of scientist awards from the Medical Research Council and AHFMR.

\section{REFERENCES}

Abrams J \& Grundy S 1981 Cholesterol metabolism in hypothyroidism and hyperthyroidism in man. Fournal of Lipid Research 22 323-338.

Abrams JJ, Grundy SM \& Ginsberg H 1981 Metabolism of plasma triglyceride in hypothyroidism and hyperthyroidism in man. Fournal of Lipid Research 22 307-322.

Apostolopoulos JJ, Howlett GJ \& Fidge N 1987 Effects of dietary cholesterol and hypothyroidism on rat apolipoprotein mRNA metabolism. Fournal of Lipid Research 28 642-648.

Applebaum-Bowden D, McLean P, Steinmetz A, Fontana D, Matthys C, Warnick GR, Cheung M, Albers JJ \& Hazzard WR 1989 Lipoprotein, apolipoprotein, and lipolytic enzyme changes following estrogen administration in postmenopausal women. Fournal of Lipid Research 30 1895-1906.

Archer TK, Tam SP \& Deeley RG 1986 Kinetics of estrogendependent modulation of apolipoprotein A-I synthesis in human hepatoma cells. Fournal of Biological Chemistry 261 5067-5074. 
Ashley JM, Lowe NJ, Borok ME \& Alfin-Slater RB 1988 Fish oil supplementation results in decreased hypertriglyceridemia in patients with psoriasis undergoing etretinate or acitretin therapy. Fournal of the American Academy of Dermatology 19 $76-82$.

Aviram M, Luboshitzky R \& Brooks JG 1982 Lipid and lipoprotein pattern in thyroid dysfunction and the effect of therapy. Clinical Biochemistry 15 62-66.

Ballantyne FC, Eppentos AA, Caslake M, Forsthe S \& Ballantyne D 1979 The composition of LDL and VLDL subfractions in primary hypothyroidism and the effects of thyroid hormone replacement therapy. Clinical Science $\mathbf{5 7}$ $83-88$.

Ballantyne FC, Clark RS, Simpson HS \& Ballantyne D 1982 The effect of moderate physical exercise on the plasma lipoprotein subfractions of male survivors of myocardial infarction. Circulation 65 913-918.

Barter PJ \& Rye KA 1996 Molecular mechanisms of reverse cholesterol transport. Current Opinion In Lipidology 7 82-87.

Beato M, Herrlich P \& Schultz G 1995 Steroid hormone receptors: many actors in search of a plot. Cell $\mathbf{8 3}$ 851-857.

Berthou L, Staels B, Saldicco I, Berthelot K, Casey J, Fruchart J-C, Denefle P \& Branellec D 1994 Opposite in vitro and in vivo regulation of hepatic apolipoprotein AI gene expression by retinoic acid. Arteriosclerosis and Thrombosis 14 1657-1664.

Brun L, Gagne C, Coulombe P, Lupien P, Dussault H \& Moorjani S 1980 Effects of dextrothyroxine on the pituitarythyroid axis in hypercholesterolemic children and goitrous adults. Fournal of Clinical Endocrinology and Metabolism $\mathbf{5 1}$ $1306-1310$.

Carr FE \& Wong NCW 1994 Characteristics of a negative thyroid hormone response element (TRE). Fournal of Biological Chemistry $2694175-4179$.

Carr FE, Kaseem LL \& Wong NCW 1992 Thyroid hormone inhibits TSH gene expression via a position independent negative T3RE. Fournal of Biological Chemistry 267 18689-18694.

Chan J, Nakabayashi H \& Wong NCW 1993 HNF-4 increases rat apolipoprotein A1 gene expression. Nucleic Acids Research 21 1205-1211.

Colvin PL, Auerbach BJ, Case D, Hazzard WR \& ApplebaumBowden D 1991 A dose-response relationship between sex hormone-induced change in hepatic triglyceride lipase and high-density lipoprotein cholesterol in postmenopausal women. Metabolism 40 1052-1056.

Croston GE, Milan LB, Marschke KB, Reichman M \& Briggs MR 1997 Androgen receptor-mediated antagonism of estrogen-dependent low density lipoprotein receptor transcription in cultured hepatocytes. Endocrinology 138 3779-3786.

Danner SA, Wieling W, Havekes L, Leuven JG, Smit EM \& Dunning AJ 1984 Effect of physical exercise on blood lipids and adipose tissue composition in young healthy men. Atherosclerosis $\mathbf{5 3} 83-90$.

Elshourbagy NA, Boguski MS, Liao WS, Jefferson LS, Gordon JI \& Taylor JM 1985 Expression of rat apolipoprotein A-IV and A-I genes: mRNA induction during development and in response to glucocorticoids and insulin. Proceedings of the National Academy of Sciences of the USA 82 8242-8246.

Engelken SF \& Eaton RP 1980 Thyroid hormone induced dissociation between plasma triglyceride and cholesterol regulation in the rat. Endocrinology 107 208-214.

Ettinger WH, Klinefelter HF \& Kwiterovitch PO 1987 Effect of short-term, low-dose corticosteroids of plasma lipoprotein lipids. Atherosclerosis 63 167-172.
Feely J, Iqbal S, Isles T \& Bakry M 1980 Total cholesterol in/HDL-cholesterol ratio in hyperthyroidism, hypothyroidism and subclinical hypothyroidism. Hormone Research 12 560-561.

Franceschini G, Maderna P \& Sirtori CR 1991 Reverse cholesterol transport: physiology and pharmacology. Atherosclerosis 88 99-107.

Fuernkranz HA, Wang Y, Karathanasis SK \& Mak P 1994 Transcriptional regulation of the apoAI gene by hepatic nuclear factor 4 in yeast. Nucleic Acids Research 25 $5665-5671$.

Giller T, Hennes U \& Kempen HJ 1995 Regulation of human apolipoprotein AI expression in Caco-2 and HepG2 cells by all-trans and 9-cis retinoic acids. Fournal of Lipid Research 36 1021-1028.

Ginsburg GS, Ozer J \& Karathanasis SK 1995 Intestinal apolipoprotein AI gene transcription is regulated by multiple distinct DNA elements and is synergistically activated by the orphan nuclear receptor, hepatocyte nuclear factor 4. Fournal of Clinical Investigation 96 528-538.

Godsland IF, Wynn V, Crook D \& Miller NE 1987 Sex, plasma lipoprotein, and atherosclerosis: prevailing assumptions and outstanding questions. American Heart Fournal 114 1467-1503.

Harnish DC, Malik S \& Karathanasis SK 1994 Activation of apolipoprotein AI gene transcription by the liver-enriched factor HNF-3. Fournal of Biological Chemistry 269 28220-28226.

Harnish DC, Malik S, Kilbourne E, Costa R \& Karathanasis SK 1996 Control of apolipoprotein AI gene expression through synergistic interactions between hepatocyte nuclear factors 3 and 4. Fournal of Biological Chemistry 271 $13621-13628$.

Harnish DC, Evans MJ, Scicchitano MS, Bhat RA \& Karathanasis SK 1998 Estrogen regulation of the apolipoprotein AI gene promoter through transcription factor sharing. Fournal of Biological Chemistry 273 9270-9278.

Hazzard WR, Haffner SM, Kushwaha RS, Aplebaum-Bowden D \& Foster DM 1984 Preliminary report: kinetic studies on the modulation of HDL, apolipoprotein, and subfraction metabolism by sex steroids in a postmenopausal woman. Metabolism: Clinical and Experimental 33 779-789.

Heiss G, Johnson J, Reilan S, Dais CE \& Tyroler HA 1980 The epidemiology of plasma HDL cholesterol levels. Circulation 62 IV116-IV136.

Huttunen JK, Lansimies E, Voutilainen E, Ehnholm C, Hietanen E, Penttila I, Siitonen O \& Rauramaa R 1979 Effect of moderate physical exercise on serum lipoproteins. A controlled clinical trial with special reference to serum high-density lipoproteins. Circulation 60 1220-1229.

Jin FY, Kamanna VS \& Kashyap ML 1998 Estradiol stimulates apolipoprotein A-I- but not A-II-containing particle synthesis and secretion by stimulating mRNA transcription rate in Hep G2 cells. Arteriosclerosis Thrombosis and Vascular Biology 18 999-1006.

Kalin MC \& Zumoff B 1990 Sex hormones and coronary disease: a review of the clinical studies. Steroids $\mathbf{5 5}$ 331-353.

Kaptein A, de Wit EC \& Princen HM 1994 Retinoids stimulate ApoAI synthesis by induction of gene transcription in primary hepatocyte cultures from cynomolgus monkey (Macaca fascicularis). Arteriosclerosis and Thrombosis $\mathbf{1 3}$ 1505-1514. Erratum 14839.

Kashyap ML 1989 Basic considerations in the reversal of atherosclerosis: significance of HDL in stimulating reverse cholesterol transport. American Fournal of Cardiology $\mathbf{6 3}$ $56 \mathrm{H}-59 \mathrm{H}$. 
Kaste M, Muuronen A, Nikkila EA \& Neuvonen PJ 1983 Increase of low serum concentrations of HDL cholesterol in TIA-patients treated with phenytoin. Stroke 4 525-530.

Kris-Etherton P, Fosmire M, Mela D \& Etherton T 1982 Studies on the etiology of increased tissue cholesterol concentration in cholesterol-fed hypothyroid rats. Fournal of Nutrition 112 2324-2332.

Ladias JAA \& Karathanasis SK 1991 Regulation of the apolipoprotein AI gene by ARP-1, a novel member of the steroid receptor superfamily. Science 251 561-565.

Larosa JC 1995 Androgens and women's health: genetic and epidemiologic aspects of lipid metabolism. American fournal of Medicine 98 22S-26S.

Laudet V 1997 Evolution of the nuclear receptor superfamily: early diversification from an ancestral orphan receptor. Fournal of Molecular Endocrinology 19 207-226.

Luoma PV 1997 Gene activation, apolipoprotein A-I/high density lipoprotein, atherosclerosis prevention and longevity. Pharmacology and Toxicology 81 57-64.

McConnell MV, Vavouranakis I, Wu LL, Vaughan DE \& Ridker PM 1997 Effects of a single, daily alcoholic beverage on lipid and hemostatic markers of cardiovascular risk. American Fournal of Cardiology 80 1226-1228.

Malik K \& Karathanasis SK 1996 TFIIB-directed transcriptional activation by the orphan nuclear receptor hepatocyte nuclear factor 4. Molecular and Cellular Biology 16 1824-1831.

Malkonen M \& Manninen V 1981 Failure of thyroid hormones to maintain the normal lipoprotein pattern in rats after removal of the pituitary gland. Atherosclerosis 38 121-128.

Manttari M, Tenkanen L, Alikoski T \& Manninen V 1997 Alcohol and coronary heart disease: the roles of HDLcholesterol and smoking. Fournal of Internal Medicine 241 157-163.

Mason RL, Hunt HM \& Hurxthal L 1930 Blood cholesterol values in hyperthyroidism and hypothyroidism - their significance. New England Fournal of Medicine 203 1273-1277.

Masumoto A, Koga S, Uchida E \& Ibayashi H 1988 Effects of insulin, dexamethasone and glucagon on the production of apolipoprotein AI in cultured rat hepatocytes. Atherosclerosis 70 217-223.

Melnik BC, Bros U \& Plewig G 1987 Evaluation of the atherogenic risk of isotretinoin-induced and etretinateinduced alterations of lipoprotein cholesterol metabolism. Fournal of Investigative Dermatology 88 39S-43S.

Miettinen TA 1968 Mechanism of serum cholesterol reduction by thyroid hormones in hypothyroidism. Fournal of Laboratory and Clinical Medicine 71 537-547.

Miller NE 1987 Associations of high-density lipoprotein subclasses and apolipoproteins with ischemic heart disease and coronary atherosclerosis. American Heart Fournal 113 589-597.

Miller NE, Laville A \& Crook D 1985 Direct evidence that reverse cholesterol transport is mediated by high-density lipoprotein in rabbit. Nature 314 109-111.

Mooradian AD, Shuh GN \& Wong NCW 1996 Age-related changes in the responsiveness of apolipoprotein AI to thyroid hormone. American Fournal of Physiology 271 R1602-R1607.

Murao K, Bassyouni H, Taylor AH, Wanke IE \& Wong NCW 1997 Hepatocyte nuclear factor 4 inhibits the activity of site A from the rat apolipoprotein gene. Biochemistry 36 301-306.

Murray CJL \& Lopez AD 1997 Mortality by cause for eight regions of the world: global burden of disease study. Lancet 349 1469-1504.

Muuronen A, Kaste M, Nikkila EA \& Tolppanen EM 1985 Mortality from ischaemic heart disease among patients using anticonvulsive drugs: a case-control study. British Medical Fournal of Clinical Research and Education 291 1481-1483.
Naar AM, Boutin JM, Lipkin SM, Yu VC, Holloway JM, Glass CK \& Rosenfeld MG 1991 The orientation and spacing of core DNA-binding motifs dictate selective transcriptional response to three nuclear receptors. Cell $\mathbf{6 5}$ $1267-1280$.

Nagasaki A, Kikuchi T, Kurata K, Masushige S, Hasegawa T \& Kato S 1994 Vitamin A regulates the expression of apolipoprotein AI and CIII genes in the rat. Biochemical and Biophysical Research Communications 205 1510-1517.

Nakabayashi HK, Watanabe A, Saito A, Otsuru K, Sawadaishi K \& Tamaoki T 1989 Transcriptional regulation of alphafetoprotein expression by dexamethasone in human hepatoma cells. Fournal of Biological Chemistry 264 266-271.

Nikkila EA, Kaste M, Ehnholm C \& Viikari J 1978 Elevation of high-density lipoprotein in epileptic patients treated with phenytoin. Acta Medica Scandinavica 204 517-520.

O'Hara D, Porte D \& Williams RH 1966 The effect of diet and thyroxin on plasma lipids in myxedema. Metabolism 15 123-134.

Quintao ECR, Nakandakare E, Oliveira HCF, Rocha JC, Garcia RC \& Melo NR 1991 Oral estradiol-17beta raises the level of plasma high-density lipoprotein in menopausal women by slowing down its clearance rate. Acta Endocrinologica 125 657-661.

Raziel A, Rosenzweig B, Botvinic V, Beigel F, Landau B \& Blum I 1982 The influence of thyroid function on serum lipid profile. Atherosclerosis 41 321-326.

Reddy MN 1985 Effect of anticonvulsant drugs on plasma total cholesterol, high-density lipoprotein cholesterol, and apolipoproteins A and B in children with epilepsy. Proceedings of the Society for Experimental Biology and Medicine 180 359-363.

Romney JS, Chan J, Carr FE, Mooradian AD \& Wong NCW 1992 Identification of the thyroid hormone mRNA Spot 11 as apolipoprotein AI mRNA and effects of the hormone on the promoter. Molecular Endocrinology 6 943-950.

Rossner S \& Rosenqvist U 1974 Serum lipoproteins and the intravenous fat tolerance test in hypothyroid patients before and during substitution therapy. Atherosclerosis 20 $365-381$

Rottman JN, Widom RL, Nadal-Ginard B, Mahdavi V \& Karathanasis SK 1991 A retinoic acid-responsive element in the apolipoprotein gene distinguishes between two different retinoic acid response pathways. Molecular and Cellular Biology 11 3814-3820.

Sacks FM, Gerhard M \& Walsh BW 1995 Sex hormones, lipoproteins, and vascular reactivity. Current Opinion in Lipidology 6 161-166.

Saladin R, Vu-Dac N, Fruchart J-C, Auwerx J \& Staels B 1996 Transcriptional induction of rat liver apolipoprotein A-I gene expression by glucocorticoids requires the glucocorticoid receptor and a labile cell-specific protein. European Fournal of Biochemistry 239 451-459.

Schaefer EJ, Foster DM, Zech LA, Lindgren FT, Brewer B \& Levy RI 1983 The effects of estrogen administration on plasma lipoprotein metabolism in premenopausal females. Fournal of Clinical Endocrinology and Metabolism 57 262-266.

Scottolini A, Bhagavan N, Oshiro T \& Abe S 1980 Serum HDL cholesterol concentrations in hypo- and hyperthyroidsm. Clinical Chemistry 26 584-587.

Seishima M, Bisgaier CL, Davies SL \& Glickman RM 1991 Regulation of hepatic apolipoprotein synthesis in the 17alpha-ethinyl estradiol-treated rat. Fournal of Lipid Research 32 941-951.

Sladek FM, Zhong W, Lai E \& Darnell JE 1991 Liver-enriched transcription factor HNF-4 is a novel member of the steroid hormone receptor superfamily. Genes and Development 4 2352-2365. 
Smith LC, Pownall, HJ \& Gotto AM Jr 1978 The plasma lipoproteins: structure and metabolism. Annual Review of Biochemistry 47 751-777.

Srivastava RAK, Baumann D \& Schonfeld G 1993 In vivo regulation of low-density lipoprotein receptors by estrogen differs at the post-transcriptional level in rat and mouse. European Fournal of Biochemistry 216 527-538.

Staels B, van Tol A, Chan L, Verhoeven G \& Auwerx J 1991 Variable effects of different corticosteroids on plasma lipids, apolipoproteins, and hepatic apolipoprotein mRNA levels in rats. Arteriosclerosis and Thrombosis 11 760-769.

Strobl W, Gorder NL, Lui-Lee YC, Gotto AM \& Patsch W 1990 Role of thyroid hormone in apolipoprotein AI gene expression in rat liver. Fournal of Clinical Investigation $\mathbf{8 5}$ 659-667.

Tam SP, Archer TK \& Deeley RG 1985 Effects of estrogen on apolipoprotein secretion by the human hepatocarcinoma cell line, HepG2. Fournal of Biological Chemistry 260 1670-1675.

Tam SP, Archer TK \& Deeley RG 1986 Biphasic effects of estrogen on apolipoprotein synthesis in human hepatoma cells: mechanism of antagonism by testosterone. Proceedings of the National Academy of Sciences of the USA $\mathbf{8 3}$ $3111-3115$.

Tang J, Ajit K, Srivastava ES, Baumann D, Pfleger BA, Kitchens RT \& Schonfeld G 1991 In vivo regulation of apolipoprotein gene expression by estradiol and testosterone occurs by different mechanisms in inbred strains of mice. Fournal of Lipid Research 32 1571-1586.

Taylor AH, Raymond J, Dionne JM, Romney J, Chan J, Lawless DE, Wanke IE \& Wong NCW 1996a Glucocorticoid increases rat apolipoprotein AI promoter activity. Fournal of Lipid Research 37 2232-2243.

Taylor AH, Wishart P, Lawless DE, Raymond J \& Wong NCW $1996 b$ Identification of functional positive and negative thyroid hormone-responsive elements in the rat apolipoprotein AI promoter. Biochemistry 35 8281-8288
Taylor AH, Stephan ZF, Steele RE \& Wong NCW 1997 Beneficial effects of a novel thyromimetic on lipoprotein metabolism. Molecular Pharmacology 52 542-547.

Umesono K, Murakami KK, Thompson CC \& Evans RM 1991 Direct repeats as selective response elements for the thyroid hormone, retinoic acid and vitamin D3 receptors. Cell 65 1255-1266.

Valdemarsson S 1983 Plasma lipoprotein alterations in thyroid dysfunction. Acta Endocrinologica 255 1-52.

Vandenbrouck Y, Janvier B, Loriette C, Bereziat G \& Mangeney-Andreani M 1995 Thyroid hormone modulates apolipoprotein-AI gene expression at the post-transcriptional level in Hep G2 cells. European Fournal of Biochemistry 231 126-132.

Varma VK, Smith TK, Sorci-Thomas M \& Ettinger WH 1992 Dexamethasone increases apolipoprotein AI concentrations in medium and apolipoprotein AI mRNA abundance from HepG2 cells. Metabolism 41 1075-1080.

Wahlqrist ML, Fidge NH \& Lomas J 1977 Lipoprotein composition in hypothyroidism. Clinica Chimica Acta 77 269-274.

Windler EET, Kovanen PT, Chao YS, Brown MS, Havel RJ \& Goldstein JL 1980 The estradiol-stimulated lipoprotein receptor of rat liver. Fournal of Biological Chemistry 255 10464-10471.

Wong NCW \& Oppenheimer JH 1986 Multihormonal regulation and kinetics of induction of a hepatic mRNA sequence which is slowly responsive to triiodothyronine. Fournal of Biological Chemistry 261 10387-10393.

Zech LA, Gross EG, Peck GL \& Brewer HB 1983 Changes in plasma cholesterol and triglyceride levels after treatment with oral iso-tretinoin. Archives of Dermatology 119 987-993.

RECEIVED 6 July 1998 